\title{
Profile of rational thinking ability skills and student learning motivation in physics learning
}

\author{
Sheila Fitriana* and Nana Mardiana \\ Universitas Islam Sumatera Utara, Department of Physics Education, Medan 20217, Indonesia
}

\begin{abstract}
Based on observations in the field, the learning process of Physics is still teacher-centered and does not provide opportunities for students to build their own knowledge through rational thinking skills. The research aims to describe the profile of rational thinking skills and student motivation. The research method used descriptive research with a single case design for the 32 students of SMPS AL WASHLIYAH 8 , who are studying temperature and heat. The technique sampling used accidental sampling or convenience sampling. The results showed that students' rational thinking skills were still low, aspects of students' remembering, classifying and evaluating skills were at the highest achievement with percentages of $94 \%$, $95 \%$, and $95 \%$ respectively, aspects of generalizing skills were in the medium category with a percentage of $70 \%$, while the aspect of comparing and analyzing skills is in the very low category with percentages of $30 \%$ and $48 \%$, respectively. The student's learning motivation profile includes the variables of persevering in facing tasks, being tenacious in facing difficulties, showing interest, and independent learning showing results in the medium category. Based on the results of the study, it is necessary to conduct an in-depth experimental study to see the success in improving the rational thinking skills of junior high school students in learning physics.
\end{abstract}

\section{Introduction}

Physics is one of the fields of Natural Sciences (IPA). Science is related to how to find out about nature systematically, so that science does not only have a collection of knowledge in the form of facts, concepts, or principles but is also a process of discovery [1]. Science has a goal that is closely related to learning with the environment and everyday life. This is in line with the various science learning objectives in the 2013 curriculum. Science education emphasizes providing direct experience to develop competencies so that students are able to explore and understand the natural surroundings scientifically [2].

Based on this context, a student must use scientific methods, namely exploring knowledge through investigation or research, communicating his knowledge with others, using thinking skills, using scientific attitudes and values. One of the abilities that students must have is the ability to think rationally. Rational thinking belongs to the stage 1 thinking hierarchy, because aspects of basic thinking skills are prerequisites for complex thinking [3]

Thinking activities are carried out using basic thinking skills and complex thinking skills. Basic thinking skills include qualifications, classifications, variable relationships, transformations, and causal relationships [4]. Complex thinking skills include problem solving, decision making, critical thinking, and creative thinking. Rational thinking skills are the basis of complex thinking skills that can be trained on students.

In rational thinking students are required to use data, principles, and logic, to determine cause and effect and draw conclusions. Students are required to use certain appropriate cognitive strategies to test the reliability of problem-solving ideas. The emergence of the idea to develop process skills and the development of CBSA is an operational manifestation of the emphasis on thinking skills in the teaching and learning process. Development in the field has not been carried out properly. The ability to think is still not developed, the teacher conditions and motivates students to learn to think through various subjects. Physics is one of the subjects that can train rational thinking skills. According to [4] we are not teaching students to think (teaching of thinking) but through learning students are invited to think (teaching for thinking). The teacher provides more opportunities for students to think, through planned activities. Rational thinking activities are: remembering, imagining, classifying, generalizing, comparing, evaluating, analyzing, synthesizing, deducing, and inferring [5].

In detail, rational thinking activities are described as follows: (1) remembering does not mean remembering "dead" knowledge but remembering those that use reason/mind; (2) imagining is creating works that can be in the form of writing, images from imagination; (3) to classify is to classify objects based on certain criteria; (4) generalizing is looking for an orderly pattern from some observed objects; (5) comparing is looking for

\footnotetext{
* Corresponding author: sheila.fitriana01@gmail.com
} 
similarities and differences of existing objects based on existing criteria; (6) evaluating is writing something by stating relevant reasons; (7) analyzing is looking for a pattern of regularity through classifying, comparing or generalizing; (8) synthesizing is through the aspects of classifying, generalizing, comparing, and evaluating to find a new regularity pattern; (9) deduction is connecting between concepts and facts that occur to find a solution; (10) conclude is the integration of rational thinking activities.

The ability to think rationally is needed in analyzing a phenomenon or event scientifically. Thinking rationally students become more able to think sensibly and criticize all events based on scientific. Science is also one of the characteristics or attitudes needed in independent and modern science learning [6].

Based on the results of interviews with teachers and initial observations at one of the schools at SMPS Medan City, it shows that there are several problems in learning physics, including: there are still many students who talk to their friends during teaching and learning activities, do not pay attention to teacher explanations, are reluctant to ask, very a lot while the time allocation for teaching and learning activities is limited, and students' reading interest is lacking. This lack of interest in reading is proven by the lack of students reading physics textbooks that are already available in the library. So that students do not understand the material presented by the teacher. Another student's difficulty is understanding questions that are in the form of calculations, as well as questions that are in the form of grouping several statements at the time of practice at the end of learning.

In line with the results of the latest Study Program for International Students Assessment (PISA), in 2018 that Indonesian students were ranked 75th out of 80 countries in the field of science. The assessment was published by The Organization for Economic Cooperation and Development (OECD). The average math score of Indonesian children is 375 , the average reading score is 396 , and the average score for science is 382. In fact, the average OECD scores are 494, 496, and 501 respectively. The scientific literacy ability of Indonesian students is still classified as low and experiencing a decline, according to the results of the Program for International Student Assessment (PISA). In the field of scientific literacy, the results of the 2015 PISA assessment showed that Indonesian students only achieved a score of 403 from the average score of 493 OECD countries [7]. While the results of the 2018 PISA assessment, Indonesian students experienced a decrease in their score to 396 from the average score of OECD countries, which was 489 [8]. Physics learning that has been designed has not been realized optimally.

Based on the description above, the authors are interested in revealing the ability of rational thinking skills and students' motivation to learn physics in junior high school. The purpose of this study is to describe the profile of students' rational thinking skills and describe the profile of students' motivation to learn physics.

\section{Methodology}

The research method used in this research is descriptive research with a single case design research design. Descriptive research is research that examines the status of the state of something in accordance with current conditions or past conditions. Research like this only describes the achievements, attitudes, behaviors or other characteristics of a group of subjects. Descriptive research reports as it is and does not involve manipulation of independent variables [9]. The single case research design is case study research that places a case as the focus of the research.

The population in this study were all seventh-grade students who took or followed the temperature and heat material at SMPS AL WASHLIYAH 8. The sample in this study was class VIIA, totaling 32 students who were studying temperature and heat material. Sample selection was done by accidental sampling or convenience sampling.

The research instruments used in this study are: The research instruments used in this study are:

\subsection{Learning Observation Sheet}

This observation sheet was made with the aim of knowing the extent to which the implementation of learning activities carried out by the teacher. The observation sheet consists of an observation sheet for teachers and an observation sheet for students. The observation sheet that is made contains the model/method of learning carried out by the teacher and the observation sheet of student activities in learning activities.

\subsection{Rational Thinking Skills Test}

The test used to measure rational thinking skills is in the form of essay questions. This question is based on indicators of rational thinking skills which include remembering, classifying, comparing, evaluating, generalizing and analyzing. In this study, the test instrument used is an instrument that has been tested for validity and reliability so that it remains to be used in research.

\subsection{Student Learning Motivation Questionnaire}

Students' learning motivation in this study focused on four variables, namely, persevering in facing tasks, being tenacious in facing difficulties, showing interest, and independent learning consisting of each indicator (found in the appendix). The variable instrument of student learning motivation used was 20 statement items which were divided into positive and negative statements. The statement is equipped with 4 answer options, namely SS (Strongly Agree), S (Agree), TS (Disagree), STS (Strongly Disagree), Each proposed answer choice has a score between 1 to 4 . Variable scores can be obtained by adding up all item scores.

In this study the variable instrument of student learning motivation used is an instrument that has been 
tested for validity and reliability so that it remains to be used in research.

\subsection{Teacher and Student Interview Sheet}

The teacher interview sheet was made with the aim of exploring the learning system carried out by the teacher starting from the opening, core and closing activities. The aspects that were asked in the interview were adjusted to the learning aspects contained in the questionnaire including the clarity of the subject matter, the existence of real experiences in learning (demonstrations and experiments), student involvement in learning, practice questions, evaluations and student paradigms about physics subjects.

The data obtained from questionnaires and tests in this study are quantitative data that will be analyzed descriptively by percentage with the steps as follows [10]:

1. Calculating the value of the respondent and each aspect or sub variable.

2. Recap values.

3. Calculate the average value.

4. Calculate the percentage with the formula:

$$
D P=n / N \times 100 \%
$$

Information:

$\mathrm{DP}=$ Descriptive Percentage $(\%)$

$\mathrm{n}=$ empirical score (score obtained)

$\mathrm{N}=$ Ideal Score for each question item

To determine the type of descriptive percentage obtained by each indicator in the variable, and the descriptive percentage calculation is then interpreted into sentences [11].

Table 1. Descriptive Analysis Criteria Percentage

\begin{tabular}{|c|c|c|}
\hline No. & Percentage & Criteria \\
\hline 1. & $90 \leq \mathrm{N} \leq 100$ & Very High \\
\hline 2. & $80 \leq \mathrm{N}<90$ & Tall \\
\hline 3. & $65 \leq \mathrm{N}<80$ & Medium \\
\hline 4. & $55 \leq \mathrm{N}<65$ & Low \\
\hline 5. & $0 \leq \mathrm{N}<55$ & Very Low \\
\hline
\end{tabular}

\section{Results and Discussion}

\subsection{Observation Results}

\subsubsection{The results of the observation of the learning model/method carried out by the teacher}

During the case study, the researcher also observed the teacher in teaching. In general, the teacher gives lessons with the lecture method interspersed with several questions and discussion of questions. The teacher performs apperception and motivation, in learning the teacher sometimes demonstrates first and then forms a group, the teacher does not assess aspects of student performance and the teacher only assesses reports on the results of the practicum carried out by students, the teacher does not ask students to convey the results in front of the class, the teacher only going around while confirming student answers in the form of calculation results, the teacher does not openly conclude in front of the class on the results of the practicum but only confirms to each group. The results of other observations of researchers are:

1. The teacher uses the lecture method from beginning to end which is interspersed with questions and answers and discussion of sample questions

2. Students are passive, just sitting quietly watching, but there are some who talk to each other

3. Students answer the teacher's questions on the sidelines of learning, some are biased to answer but some are silent without answering the teacher's questions

4. Only a few students dared to try in front of the class to answer the exercises given by the teacher, while others did not dare to even do the practice questions given by the teacher.

5. At the end of the lesson the teacher concludes the subject matter that has been studied and sometimes gives assignments at the end of the lesson.

\subsubsection{The results of observing student activities}

All students pay attention to apperception and motivation by the teacher. There are some students in the back who don't listen to the teacher's explanation carefully and only a few students in the front pay attention to the demonstration made by the teacher. Students are quite active in asking and answering questions posed by the teacher. Students want to work together in groups and exchange opinions.

\subsubsection{Rational Thinking Skills Test Results}

Based on the results of the recapitulation of the rational thinking skills test, the following data were obtained:

Table 2. Rational Thinking Skills Test Results

\begin{tabular}{|c|c|c|c|c|}
\hline No & Aspect & $\begin{array}{c}\text { Question } \\
\text { Number }\end{array}$ & $\begin{array}{c}\text { Percentage } \\
(\%)\end{array}$ & Criteria \\
\hline 1 & Remembering & 1 & 94 & $\begin{array}{c}\text { Very } \\
\text { High }\end{array}$ \\
\hline 2 & Classifying & 2 & 95 & $\begin{array}{c}\text { Very } \\
\text { High }\end{array}$ \\
\hline 3 & Comparing & 3 & 30 & $\begin{array}{c}\text { Very } \\
\text { Low }\end{array}$ \\
\hline 4 & Evaluating & 4 & 95 & $\begin{array}{c}\text { Very } \\
\text { High }\end{array}$ \\
\hline 5 & Generalizing & 5 & 70 & Medium \\
\hline 6 & Analyzing & 6 & 48 & $\begin{array}{c}\text { Very } \\
\text { Low }\end{array}$ \\
\hline
\end{tabular}

The next diagram the average percentage ratio of rational thinking skill tests as a whole are presented in the following diagram: 


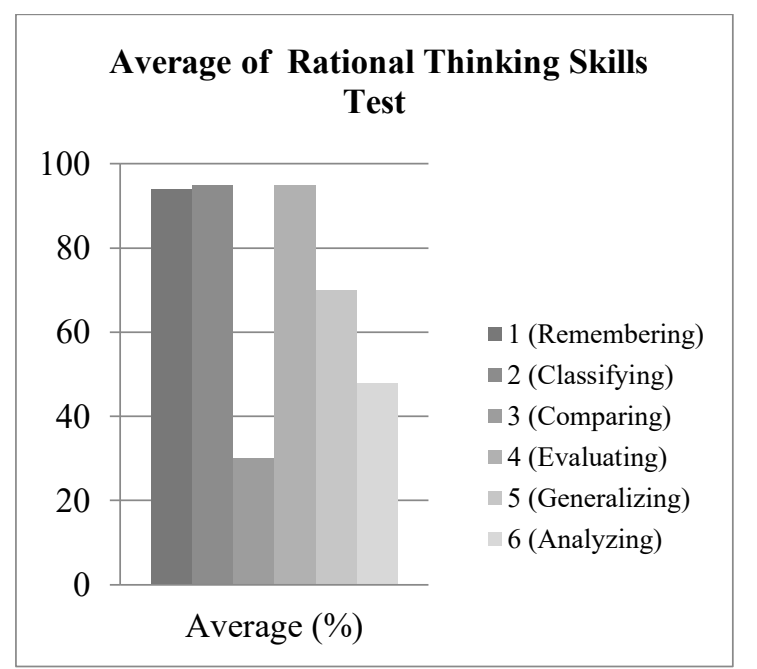

Fig. 1. Comparison diagram of the average test of rational thinking skills

\subsubsection{The results of the questionnaire on students' motivation towards learning physics}

Based on the results of the student motivation questionnaire recapitulation, the following data were obtained:

Table 3. Results of Student Motivation Questionnaire Recapitulation

\begin{tabular}{|c|c|c|c|}
\hline Variabels & $\begin{array}{c}\text { Question } \\
\text { Number }\end{array}$ & Average & Criteria \\
\hline $\begin{array}{c}\text { Persevere to face } \\
\text { Task }\end{array}$ & $1,4,5,13,14$ & 75 & Medium \\
\hline $\begin{array}{c}\text { Persevere in the } \\
\text { face of adversity }\end{array}$ & $2,3,7,15,16$ & 68 & Medium \\
\hline Show interest & $8,10,12,17,18$ & 69 & Medium \\
\hline $\begin{array}{c}\text { Learn to be } \\
\text { independent }\end{array}$ & $6,9,11,19,20$ & 70 & Medium \\
\hline
\end{tabular}

Next is a diagram that shows the students' overall learning motivation:

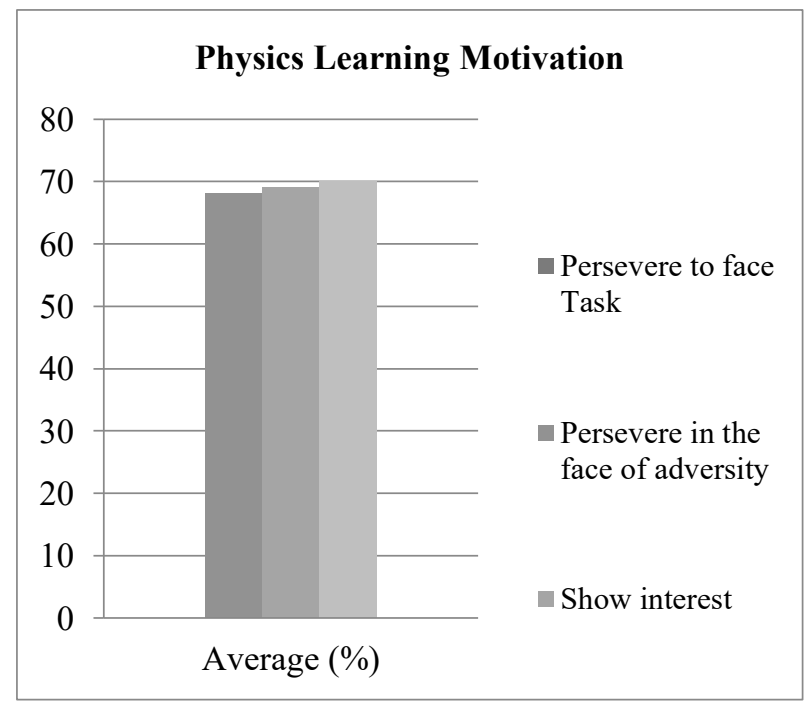

Fig. 2. Diagram of students' motivation to learn physics

\subsection{Discussion}

Based on the test results of the rational thinking skills test, it can be seen that the students' rational thinking skills can be described as follows:

1. Aspects of students' remembering, classifying and evaluating skills are at the highest achievement with percentages of $94 \%, 95 \%$, and $95 \%$ respectively

2. Aspects of generalizing skills are in the medium category with a percentage of $70 \%$ for questions related to explaining the effect of heat on the increase in object temperature.

3. The aspect of comparing and analyzing skills is in the very low category with percentages of $30 \%$ and $48 \%$, respectively. This is indicated by the results of student answers relating to the ability of students to sort the temperature from the highest to the lowest temperature in a simple experiment and using the equation $\mathrm{Q}=$ m.c. $\Delta \mathrm{T}$ in events in everyday life in the questions most of the students are unable to answer correctly.

The results of the student's rational thinking skills test have not been maximized, allegedly caused by several things as follows:

1. Students are less accustomed to answering teacher questions, expressing their ideas, and responding to other students' ideas, reporting and comparing group discussion results so it is recommended for teachers to guide, motivate, and facilitate students to practice students' rational thinking skills.

2. Students are not accustomed to working on test questions that measure rational thinking skills, because usually students only get questions that only touch aspects of memory or understanding. Therefore, it is recommended that teachers facilitate more students to practice questions that are able to construct their rational thinking skills.

In addition to students' rational thinking skills, data on the motivation to learn physics for junior high school students was also obtained. Students' motivation to learn physics is still in the medium category. This is shown from the results of interviews and questionnaires that have been given to students. Based on the motivational questionnaire conducted by students, it is known that most students feel less interested and enthusiastic about physics lessons. In general, students are less motivated to study physics, this is caused by several factors, including:

1. Students feel bored with physics lessons because the teacher always teaches by the lecture method

2. Too many formulas to understand and memorize 3. Students feel incomplete in understanding the lesson, this is because the teacher does not fully explain and limited time.

After exploring what students want when studying physics, the results are as follows:

1. Students want teachers to apply innovative and creative learning models so they are not boring

2. Students want to do physics experiments 
3. Learning is interspersed with games related to physical phenomena.

In general, the teacher gives lessons with the lecture method interspersed with several questions and discussion of questions. The following are the results of the researchers' observations:

1. The teacher uses the lecture method from beginning to end which is interspersed with questions and answers and discussion of sample questions

2. Students are passive, just sitting quietly watching, but there are some who talk to each other

3. Students answer the teacher's questions on the sidelines of learning, some are biased to answer but some are silent without answering the teacher's questions

4. Only about 4 students dared to try in front of the class to answer the exercises given by the teacher, while the others did not dare to even do the practice questions given by the teacher.

5. At the end of the lesson the teacher gives homework.

\section{Conclusions}

1. Rational thinking skills are still relatively low, aspects of students' remembering, classifying and evaluating skills are at the highest achievement with percentages of $94 \%, 95 \%$, and $95 \%$ respectively, aspects of generalizing skills are in the medium category with a percentage of $70 \%$, while the aspect of comparing and analyzing skills is in the very low category with percentages of $30 \%$ and $48 \%$, respectively.

2. Most student learning motivation towards learning of physics is medium.

\section{References}

1. Depdiknas, Pengembangan Bahan Ujian dan Analisis Hasil Ujian: Materi Presentasi Sosialisasi KTSP Jakarta: Departemen Pendidikan Nasional (2006)

2. Rahayu. P, Mulyani. S., et al, Jurnal Pendidikan IPA Indonesia., 1(1), 63-70 (2012)

3. Farida. Ida, Jurnal Pendidikan MIPA, 1,8 (2006)

4. Costa. Arthur., Developing Minds A Resource Book for Teaching Thinking. Virginia: Association for Supervision and Curriculum Development, 44-45 \& 20-21 (1985)

5. Novak. J.D, Gowin. D. B., Learning How to Learn , 255 (1984)

6. Nurachma. D. E., Irawan. E., Integrative Science Education and Teaching Activity Journal., 1(1), 34-44 (2020)

7. OECD, PISA Result in Focus (2015b)

8. OECD, Programme for International Student Assessment (PISA), 1-10. (2018)

9. McMillan. J.H, Schumacher. S., Research in Education. New York: Longman, Inc, 397 (2001)

10. Riduwan, Akdon, Rumus dan Data dalam Analisis Statistika, 71-95 (2010)
11. Arikunto, S. Prosedur Penelitian Suatu pendekatan praktik. Jakarta: PT. Rineka Cipta (2011) 